\title{
Pengelolaan Arsip Dinamis Inaktif di Lembaga Pendidikan Sekolah Menengah Kejuruan
}

\author{
Aria Mulyapradana ${ }^{1}$, Ary Dwi Anjarini ${ }^{2}$, Nanang Hermanto ${ }^{3}$ \\ 1,2,3 Politeknik Pusmanu, Pekalongan \\ Jl. Karangdowo No 9 Kedungwuni, Kabupaten Pekalongan, Indonesia \\ e-mail: ${ }^{1}$ ariamulya@politeknikpusmanu.ac.id, ${ }^{2}$ arydwianjarini@ politeknikpusmanu.ac.id, \\ 3 anangherman03@gmail.com
}

\begin{abstract}
Informasi Artikel Diterima: 01-02-2021 Direvisi: 23-02-2021 Disetujui: 28-02-2021

Abstrak

Arsip mempunyai peranan yang sangat penting bagi sebuah organisasi pendidikan seperti di Sekolah Menengah Kejuruan Diponegoro Karanganyar Kabupaten Pekalongan sebagai lembaga pendidikan berhubungan kegiatan administrasi dan kearsipan baik arsip mengenai data siswa, kurikulum dan administrasi umum lainnya tentunya perlu melakukan pengelolaan arsip yang baik agar dapat mendukung kelancaran dalam produktivitas sekolah serta pengambilan keputusan. Arsip dinamis inaktif merupakan arsip yang pemanfaatannya tidak secara langsung dan sering dibutuhkan. Arsip dinamis inaktif meski jarang dibutuhkan namun biasanya merupakan arsip yang termasuk ke dalam arsip penting atau vital yang dimana keamanan dan keberadaanya harus mendapatkan perhatian dan pengelolaan yang baik sehingga suatu saat dibutuhkan akan mudah untuk ditemukan dan terlebih bila dibutuhkan untuk keperluan pengambilan kebijakan organisasi. Riset ini bertujuan untuk mengetahui bagaimana pengelolaan arsip dinamis inaktif di SMK Diponegoro Karanganyar Kabupaten Pekalongan Bagian Tata Usaha. Metode dalam riset ini menggunakan metode deskiptif kualitatif melalui pengumpulan data dengan teknik observasi, wawancara, dan dokumentasi. Hasil riset ini menunjukkan masih terdapat kendala yang seperti sistem informasi dalam pengelolaan arsip masih manual, tata letak ruangan kerja yang belum rapih, keterbatasan ruang penyimpanan arsip, keterbatasan sarana prasarana penunjang kearsipan dan keterbatasan sumber daya manusia dalam pengelolaan arsip. Berdasarkan hasil riset tersebut bahwa sistem pengelolaan arsip masih belum maksimal dan perlu menjadi perhatian oleh pimpinan agar pengelolaan arsip dapat tertata dengan baik dan efektif.
\end{abstract}

Kata kunci: Pengelolaan Arsip, Arsip dinamis in aktif, Tata Usaha

\begin{abstract}
Archives have a very important role for an educational organization such as the Diponegoro Karanganyar Vocational High School, Pekalongan Regency as an educational institution related to administrative and archival activities, both archives regarding student data, curriculum and other general administration, of course, need to carry out good archive management in order to support smooth operations. school productivity and decision making. Inactive dynamic archives are records that are used indirectly and are often needed. Inactive dynamic archives, although rarely needed, are usually archives that are included in important or vital archives where security and their existence must get attention and good management so that one day they are needed, they will be easy to find and especially if needed for organizational policy making purposes. This research aims to find out how inactive dynamic archive management at SMK Diponegoro Karanganyar, Pekalongan Regency Administration Section. The method in this research uses qualitative descriptive methods through data collection with observation, interview, and documentation techniques. The results of this research indicate that there are still obstacles such as manual information systems in archive management, uncluttered workspace layout, limited archive storage space, limited supporting infrastructure for archives and limited human resources in managing records. Based on the research results, the archive management system is still not optimal and needs to be paid attention by the leadership so that the management of archives can be well organized and effective.
\end{abstract}

\section{Keywords: Archive management, dynamic archive in active, Administration}

\section{Pendahuluan}

Kantor sebagai pusat kegiatan administrasi dituntut untuk mampu memberikan informasi yang dibutuhkan secara cepat, tepat, dan lengkap. Informasi tersebut dapat digunakan sebagai dasar dalam pengambilan keputusan dan penentuan kebijakan. Informasi mempunyai peran penting untuk membantu proses pelaksanaan kegiatan dan juga sebagai bahan pertimbangan untuk meminimalisir kemungkinan kesalahan yang terjadi. 
Pelaksanaan kegiatan administrasi di setiap kantor selalu diarahkan untuk tercapainya keberhasilan dari tujuan organisasi secara efektif dan efisien. Salah satu faktor yang dapat menunjang keberhasilan kantor dalam mencapai tujuan yaitu ketertiban dalam bidang administrasi. Suatu bidang administrasi yang ada di dalam sebuah kantor antara lain kegiatan pengelolaan arsip.

Arsip menurut Undang-Undang No. 43 Tahun 2009 menjelaskan bahwa pengertian arsip adalah "rekaman peristiwa atau kegiatan yang diterima oleh lembaga negara, pemerintah daerah, perusahaan, organisasi politik, lembaga pendidikan, dan perseorangan untuk pelaksanaan kehidupan bermasyarakat yang berupa berbagai bentuk dan media sosial dengan perkembangan komunikasi dan perkembangan teknologi informasi". Berdasarkan pengertian arsip diatas diketahui bahwa arsip adalah naskah tertulis yang didalamnya memuat keteranganketerangan penting. Arsip sangat berperan penting dalam suatu lembaga, yaitu sebagai penyajian informasi maupun pusat ingatan bagi seorang pimpinan untuk dapat merumuskan kebijakan dan membuat keputusan, maka untuk dapat memberikan atau menyajikan informasi yang akurat dan lengkap harus memiliki prosedur tertentu dan sistem yang baik dalam pengelolaan kearsipannya. Proses yang sedemikian tersebut dapat menciptakan arsip apapun jenisnya baik yang tekstual maupun kontekstual. Arsip inilah yang suatu saat diberkaskan berdasarkan transaksi dan kegiatannya sesuai kepentingan unit kerja agar mudah dicari dan ditemukan kembali. Menurut undang-undang tentang kearsipan mengatakan bahwa arsip inaktif adalah arsip yang frekuensi penggunaanya telah menurun (Ali Muhidin, 2019).

Arsip adalah setiap catatan tertulis baik dalam bentuk gambar atau bagan yang memuat keterangan-keterangan mengenai suatu pokok persoalan atau peristiwa-peristiwa yang masih berguna dan diperlukan sewaktu-waktu di masa mendatang (Maryati, 2008)

Menurut Mulyono, Partono, dan Kuswantoro arsip adalah warkat yang disimpan dam memiliki nilai guna informasi. Oleh karenanya, dibutuhkan pengelolaan yang baik agar efektif dan efisien. Inti dari manajemen kearsipan yaitu penyimpanan (storing), penempatan (placing), dan penemuan kembali (finding) (Kuswantoro, 2015).

Adapun tujuan dari pengarsipan antara lain sebagai referensi atau bukti legalitas sewaktu-waktu arsip dibutuhkan, sebagai sumber data dan sebagai data historis (Maryati, 2008). Menurut Ana Pujiastuti bahwa fungsi arsip dapat dikelompokkan dalam 4 kepentingan yaitu; (1) arsip merupakan kebutuhan hidup manusia, (2) arsip merupakan urat nadi administrasi organisasi sebagai suatu bentuk administrasi tidak mungkin mengabaikan keberadaan arsip, (3) arsip merupakan bukti sumber informasi otentik kehidupan modern dapat dikatakan bertumpu pada ketersediaan arsip, (4) rekam kegiatan/peristiwa kehidupan modern yang memiliki kecanggihan teknologi yang cukup mengagumkan semakin memberi kemungkinan untuk menempatkan arsip sebagai rekam kegiatan atau peristiwa (Fathurrahman, 2018).

Arsip sendiri mempunyai peranan yang sangat penting bagi sebuah organisasi pendidikan seperti di Sekolah Menengah Kejuruan Diponegoro Karanganyar Kabupaten Pekalongan sebagai lembaga pendidikan yang berhubungan dengan kegiatan administrasi dan kearsipan baik arsip mengenai data siswa, kurikulum dan administrasi umum lainnya tentunya perlu melakukan pengelolaan arsip yang baik agar dapat mendukung kelancaran dalam produktivitas sekolah serta pengambilan keputusan. Arsip-arsip tersebut perlu mendapatkan perhatian khusus sehingga dapat menunjukkan perannya dalam mendukung penyelesaian dan kelancaran kegiatan yang dilaksanakan oleh organisasi tersebut, arsip tersebut yang terutama arsip dinamis aktif dan pengelolaan arsip dinamis inaktif.

Diperkuat dengan penelitian yang dilakukan oleh Muslih Fathurrahman mengatakan bahwa arsip merupakan salah satu sumber informasi penting yang dapat menunjang proses kegiatan administrasi maupun birokrasi. Sebagai rekaman informasi dari seluruh aktivitas organisasi, arsip berfungsi sebagai pusat ingatan, alat bantu pengambilan keputusan, bukti eksistensi organisasi dan untuk kepentingan organisasi yang lain (Fathurrahman, 2018). Disamping itu, menurut Susiasih Damalita dalam penelitiannya menyatakan bahwa arsip merupakan catatan sebagai memori kolektif keberadaan suatu lembaga/ Institusi. Melalui catatan itulah kini dapat tergambar perjalanan panjang sejarah keberadaan suatu lembaga dari waktu ke waktu dan memori yang tertulis dalam arsip dan sebentuk fakta selalu dapat disimak masa kini dan diwariskan kepada generasi di masa yang akan datang (Damalita, 2009).

Di SMK Diponegoro Karanganyar Kabupaten Pekalongan pada unit administrasi tata usaha merupakan tempat bank data sebagai pusat informasi bagi hampir semua administrasi sekolah, yang tentunya sangat mendukung dalam akreditasi sekolah dan dalam penentuan kebijakan sekolah. Untuk itu sebagai sumber informasi dan pusat ingatan diharapkan dapat dengan segera menemukan kembali arsip yang dibutuhkan. Namun diketahui menurut informasi penemuan kembali arsip di SMK Diponegoro Karanganyar Kabupaten Pekalongan membutuhkan waktu kurang lebih 3 sampai 5 menit terlebih bila arsip tersebut bila ternyata tidak berada di tempatnya, masih belum dikelolanya arsip dengan baik menjadikan arsip tersebut sulit untuk ditemukan kembali.

Sebagai organisasi pendidikan SMK Diponegoro Karanganyar Kabupaten Pekalongan dalam 
observasinya diketahui memiliki beberapa kendala dalam pengelolaan arsip yaitu seperti terbatasnya ruang dan sarana dan prasarana seperti perlengkapan dan peralatan kearsipan sedangkan arsip-arsip setiap harinya selalu bertambah seperti arsip aktif maupun dalam pengelolaan arsip inaktifnya masih berada pada ruang kerja administrasi dengan frekuensi yang semakin bertambah perlu pengurangan arsip sesuai jadwal retensi arsip. Dikarenakan pengelolaan arsip yang yang baik di lingkungan sekolah dengan terpenuhinya peralatan dan perlengkapan yang dibutuhkan akan dapat menjamin keselamatan dan keamanan arsip dapat terjauhkan dari kerusakan, debu, kotoran, binatang-binatang seperti rayap, kecoa yang dapat merusak arsip sebab pengelolaan arsip ini sebagai bentuk bukti kinerja sekolah maka perlu dijamin keamanan dan keselamatannya

Pengelolaan arsip dapat dikatakan baik apabila dalam penemuan kembali arsip dapat dilakukan dengan cepat dan tepat. Kenyataannya tidak semua kantor melakukan pengelolaan arsip dengan baik. Pengelolaan arsip memiliki tujuan untuk memudahkan bila suatu saat arsip akan digunakan. Untuk mencapai keberhasilan dalam suatu organisasi maka perlu adanya pengelolaan arsip dinamis inaktif dengan baik, meliputi kegiatan-kegiatan:

1. Pemindahan Arsip, merupakan kegiatan memindahkan arsip dari arsip dinamis ke arsip dinamis inaktif dan dari arsip dinamis inaktif ke arsip statis. Pemindahan arsip dilakukan setelah arsip dinyatakan inaktif, biasanya setelah suatu periode tertentu, misalnya 1 tahun, arsip sudah jarang sekali digunakan. Berapa lama arsip dinyatakan aktif atau inaktif bergantung pada kebijakan tiap-tiap instansi (Mulyapradana \& Zulaekho, 2018).

2. Penataan Arsip, merupakan proses mengklasifikasi dan mengatur arsip dalam suatu tatanan yang sistematis dan logis, serta menyimpannya dalam suatu tempat yang aman agar arsip tersebut dapat secara cepat ditemukan saat dibutuhkan (Yatimah, 2020).

3. Penyimpanan arsip adalah suatu kegiatan pemberkasan dan penataan arsip dinamis, yang penempatannya secara faktual menerapkan suatu sistem tertentu, yang biasa disebut sistem penempatan arsip secara aktual (Sanora, 2016).

4. Peminjaman Arsip, keluarnya arsip dari tempat penyimpanan karena dipinjam oleh unit lain maupun organisasi lain. Keluarnya arsip dilakukan pencatatan peminjaman arsip dengan menggunakan kartu pinjam arsip (Mulyono et al., 2011).
5. Penemuan Kembali Arsip, proses bagaimana arsip tersebut ditemukan sesuai dengan kaidah sistem kearsipan yang berlaku pada saat dibutuhkan. Kemudahan dan penemuan kembali arsip sangat penting karena setiap keputusan harus diambil dengan cepat, tepat dan cermat agar kelancaran kegiatan perkantoran tidak terganggu (Wirawanty, 2014).

6. Pemeliharaan Arsip, kegiatan terus menerus untuk mengusahakan aagar barang/bahan kantor tetap dalam keadaan baik atau siap untuk dipakai (Gavinov, 2016).

7. Pengamanan Arsip, pengamanan fisik arsip dilaksanakan dengan maksud untuk melindungi arsip dari ancaman faktor-faktor pemusnah atau perusak arsip. Ada beberapa contoh yang dapat dilakukan; penggunaan sistem keamanan ruang penyimpanan arsip, penggunaan bangunan kedap air, penggunaan struktur bangunan dan lokasi yang tidak rawan bencana dan kebakaran (Veraniasyah \& Erlangga Andi, 2019)

8. Penyusutan Arsip, merupakan kegiatan pengurangan arsip dengan jalan pemindahan arsip inaktif dari unit pengelola ke unit kearsipan, memusnakan arsip sesuai dengan ketentuan yang berlaku dan menyerahkan arsip statis kepada Arsip Nasional RI (Sedarmayanti, 2017).

Arsip yang dikelola dengan baik dapat memberikan banyak manfaat bagi perusahaan atau organisasi. Pengelolaan arsip tidaklah mudah, ada beberapa permasalahan yang timbul sehingga menyebabkan pengelolaan arsip menjadi kurang optimal. Berikut ini adalah beberapa faktor arsip yang baik, yaitu; (a) penggunaan sistem penyimpanan secara tepat, (b) fasilitas kearsipan memenuhi syarat, (c) petugas kearsipan mempunyai syarat (Ramanda \& Indrahti, 2015).

Didukung dengan penelitian yang dilakukan oleh Emi Jumiyati bahwa pengelolaan arsip dalam suatu organisasi mutlak diperlukan, karena arsip mempunyai peranan yang sangat penting bagi kehidupan organisasi. Untuk itu arsip perlu dikelola dengan baik sehingga apabila ada pihak yang membutuhkan arsip, maka arsip dapat diberikan dengan cepat dan tepat (Jumiyati, 2009).

Senada yang diungkapkan oleh Rulli Susfa Ramanda dan Sri Indrahti bahwa proses temu kembali arsip yang cukup baik dan menggunakan alat temu kembali arsip yaitu DPA dan komputer memiliki pengaruh pengelolaan arsip inaktif terhadap temu kembali arsip. Adapun yang dirasakan dalam pengelolaan arsip yang baik adalah penyelamatan fisik arsip dan tertata dengan rapi arsip tersebut serta kecepatan dalam temu kembali arsip tidak membutuhkan waktu yang lama dalam penemuan arsip (Ramanda \& Indrahti, 2015).

Berdasarkan riset awal di SMK Diponegoro Karanganyar Kabupaten Pekalongan dalam pengelolaan arsipnya belum optimal seperti penggunaan sistem kearsipan berbasis digitalisasi dan ini merupakan salah satu kurang efektifnya pengelolaan arsip dan keamanan 
arsip sebagai backup data organisasi, keterbatasan ini dikarenakan sistem yang ada masih terbatas pada penggunaan file dan folder pada program perkantoran standar yang ada di kantor namun belum ada aplikasi yang terintegrasi dengan sistem kearsipan dan belum maksimal terdigitaliasasinya dokumen-dokumen yang ada, dan hal ini perlu menjadi perhatian khusus meskipun.

Menurut undang-undang tentang kearsipan mengatakan bahwa arsip inaktif adalah arsip yang frekuensi penggunaanya telah menurun (Ali Muhidin, 2019). Arsip dinamis inaktif meski jarang dibutuhkan namun biasanya merupakan arsip yang termasuk ke dalam arsip penting atau vital yang dimana keamanan dan keberadaanya harus mendapatkan perhatian dan pengelolaan yang baik sehingga suatu saat dibutuhkan akan mudah untuk ditemukan dan terlebih bila dibutuhkan untuk keperluan pengambilan kebijakan organisasi. Sebab arsip dinamis inaktif ini memiliki rentang digunakan dalam pemanfaatnya sekitar 5 sampai 10 kali dalam satu tahunnya.

Hal lain berdasarkan hasil pengamatan awal diketahui bahwa pengelolaan arsip belum optimal dikarenakan terbatasnya pengetahuan tenaga yang mengelola arsip bukan dari bidang kearsipan sehingga pengelolaan arsip dinamis in aktif ini terbatas pada pengetahuan yang dimiliki oleh pegawai tersebut sehingga diperlukannya pelatihan dan diklat khusus untuk mampu menangani arsip secara baik.

Sebab menjadi perhatian yang sangat pentingnya pengelolaan arsip dimanis inaktif dan dari hasil pengamatan diatas maka dari itu penulis tertarik meneliti tentang Pengelolaan Arsip dinamis inaktif di lembaga pendidikan Sekolah Menengah Kejuruan Diponegoro Karanganyar Kabupaten Pekalongan.

Berdasarkan fenomena tersebut peneliti tertarik untuk mengkaji riset tentang pengelolaan arsip dinamis inaktif di SMK Diponegoro Karanganyar Kabupaten Pekalongan yang masih bersifat konvensional untuk dapat beralih ke digitalisasi melihat saat ini sudah memasuki era digitalisasi. Keterbatasan masalah dalam riset ini berfokus pada pengelolaan arsip dinamis inaktif pada bagian Tata Usaha di SMK Diponegoro Karanganyar Kabupaten Pekalongan. Dan tujuan dari riset ini adalah untuk mengetahui penerapan pengelolaan arsip dinamis inaktif di SMK Diponegoro Karanganyar Kabupaten Pekalongan.

\section{Metode Penelitian}

Jenis riset ini termasuk penelitian deskriptif dengan pendekatan kualitatif, subjek dalam riset ini adalah karyawan sekolah khususnya mereka yang bertugas di bagian Tata
Usaha sebanyak 2 orang dan beberapa unit kerja yang berkaitan dengan kegiatan pengelolaan arsip seperti pimpinan sekolah yakni kepala sekolah, bagian keuangan sebanyak 1 orang dan bagian kesiswaan sebanyak 1 orang dengan total informan dalam riset ini berjumlah lima orang. Pengumpulan data dalam riset ini dengan cara observasi dan wawancara. Objek riset dilakukan di SMK Diponegoro Karanganyar Kabupaten Pekalongan dengan durasi waktu selama empat bulan mulai dari Oktober 2020 sampai Januari 2021.

\section{Hasil dan Pembahasan} berikut :

Riset ini diperoleh hasil pembahasan sebagai

3.1 Pengelolaan Arsip Dinamis Inaktif Pada Bagian Tata Usaha Lembaga Pendidikan Sekolah Menengah Kejuruan

Pengelolaan arsip menjadi faktor penting di setiap organisasi maupun perusahaan karena adanya pengelolaan arsip yang baik maka dapat membantu organisasi atau perusahaan dalam memperoleh informasi yang akurat dan dapat menjadi acuan dalam pengambilan suatu keputusan. Adapun pengelolaan arsip dinamis inaktif meliputi pemindahan, penataan, penyimpanan, peminjaman, penemuan kembali arsip, pemeliharaan arsip, pengamanan arsip dan penyusutan arsip.

\section{a. Pemindahan Arsip}

Pemindahan arsip yang dilakukan oleh pencipta arsip ke tempat penyimpan arsip berguna untuk mengurangi terjadinya penumpukan arsip di ruang kerja dari pencipta arsip tersebut dan dilakukan secara berkala dan terus menerus. Dari hasil pengamatan yang dilakukan peneliti di objek riset tersebut yakni pemindahan arsip yang dilakukan sudah berjalan dengan lancar dan dilakukan setahun sekali pada saat berakhirnya tahun ajaran baru. Arsip dipindahkan ke ruangan khusus dan ditempatkan lemari arsip.

\section{b. Penataan Arsip}

Penataan arsip merupakan kegiatan mengklasifikasi dan mengatur arsip dalam suatu tatanan yang sistematis. Dalam hal ini objek riset telah melakukan penataan arsip yang telah dipindahkan ke ruangan khusus dan arsip ditaruh di lemari arsip dengan menggunakan box file yang disesuaikan dengan bentuk arsipnya dan tahun pelajaran.

\section{c. Penyimpanan Arsip}

Ada lima kegiatan dalam proses penyimpan arsip diantaranya adalah pelaksanaan penyimpanan arsip, sistem penyimpanan arsip, peralatan penyimpanan arsip, perlengkapan penyimpanan arsip dan ruangan dan kondisi lingkungan penyimpanan arsip.

a. Pelaksanaan Penyimpanan Arsip 
Mengenai pelaksanaan penyimpanan arsip pada objek riset sudah dilakukan dengan cara arsip yang sudah diproses atau ditindak lanjuti kemudian disimpan dalam tempat yang sudah disediakan. Sedangkan untuk arsip berkas dijilid dan disimpan di lemari.

b. Sistem Penyimpanan Arsip Sistem penyimpanan yang digunakan pada objek riset menggunakan sistem penyimpanan tunggal berdasarkan tanggal pada arsip yang disimpan. Selanjutnya penyimpanan yang dilakukan menganut asas gabungan (kombinasi) sentralisasi dan desentralisasi.

c. Peralatan Penyimpanan Arsip Pengadaan peralatan untuk menyimpan arsip sangat diperlukan, dalam hal ini objek riset memiliki peralatan penyimpanan arsip yakni lemari arsip akan tetapi jumlahnya sangat terbatas melihat volume arsip yang tercipta semakin banyak.

d. Perlengkapan Penyimpanan Arsip Dalam hal ini objek riset telah melakukan pengadaan terhadap peralatan yang diperlukan untuk penyimpanan arsip seperti box file, guide, map gantung dan ordner.

e. Ruangan dan Kondisi Lingkungan Penyimpanan Arsip

Lokasi penyimpanan arsip di objek riset ini masih tergolong terbatas baik dari segi luas bangunan dan kondisi lingkungan penyimpanan arsip masih jauh dari standar penyimpanan arsip disamping itu pula temperatur dan kelembaban udara yang masih tergolong tidak sejuk. Lokasi penyimpanan arsip berdekatan dengan lokasi kerja di bagian Tata Usaha.

\section{d. Peminjaman Arsip}

Kegiatan peminjaman arsip menjadi salah satu langkah dalam penyajian informasi. Agar arsip yang dipinjam tidak tercecer dan hilang maka diperlukan pengawasan terhadap arsip yang dipinjam adapun caranya dengan melakukan pencatatan di buku peminjaman arsip dan kartu kendali. Berdasarkan hasil pengamatan yang dilakukan peneliti di objek riset tersebut yakni ditemukan ada beberapa arsip yang masa peminjamannya tergolong lama, tidak adanya buku atau pencatatan mengenai peminjaman arsip, dan penggunaan kartu kendali yang belum berjalan sehingga proses pengawasan terhadap arsip yang keluar masih belum terlaksana dengan baik.

\section{e. Penemuan Kembali Arsip}

Terbatasnya tempat penyimpanan arsip dan sedikitnya perlengkapan arsip yang dimiliki oleh objek riset tersebut serta jumlah volume arsip yang semakin banyak mengakibatkan ada penumpukan arsip di lokasi penyimpanan arsip maupun di lokasi kerja dari pencipta arsip tersebut sehingga membutuhkan waktu untuk mencari arsip yang dibutuhkan dan berdampak pada tersendatnya proses penemuan arsip kembali.

\section{f. Pemeliharaan Arsip}

Pentingnya arsip yang digunakan sebagai sumber informasi dan pengambilan keputusan bagi organisasi maupun perusahaan maka arsip perlu dipelihara dan dirawat agar terhindar dari kerusakan baik yang disebabkan dari faktor ekstrinsik maupun faktor intrinsik.

Di objek riset tersebut kegiatan pemeliharaan arsip belum berjalan dengan baik dikarenakan terbatasnya jumlah petugas yang menangani arsip sehingga proses perawatan arsip masih terabaikan dan tidak adanya jadwal pemeliharan arsip yang terjadwal. Kegiatan membersihkan dan merapihkan arsip dilakukan sebulan sekali atau bahkan lebih.

\section{g. Pengamanan Arsip}

Pengamanan fisik arsip sangat diperlukan baik organisasi maupun perusahan hal tersebut bertujuan agar arsip yang tercipta tidak mengalami kerusakan dan hilang serta dapat menjaga kerahasiaan dari arsip tersebut.

Pengamanan arsip yang dilakukan di objek riset masih belum berjalan dengan baik hal ini terlihat pada saat observasi di lokasi bahwa lokasi arsip belum terpasang AC sehingga temperatur dan kelembaban ruangan masih terasa panas dan dijumpai adanya serangga. Melihat kondisi tersebut upaya untuk pengamanan arsip masih belum berjalan secara optimal.

\section{h. Penyusutan Arsip}

Guna menghindari penumpukan arsip dikarenakan banyaknya arsip yang tercipta yang 
berdampak pada meningkatnya jumlah volume arsip maka diperlukan penyusutan arsip berdasarkan nilai guna arsip tersebut. Penyusutan arsip di objek riset belum dilakukan secara sistematis dan optimal sehingga terjadi penumpukan arsip di ruang kerja dan tempat penyimpanan arsip dikarenakan terbatasnya tempat penyimpanan arsip dan meningakatnya volume arsip. Hal tersebut berdampak pada kinerja kearsipan di objek riset tersebut.

3.2 Hambatan Dalam Pengelolaan Arsip Dinamis Inaktif Pada Bagian Tata Usaha Lembaga Pendidikan Sekolah Menengah Kejuruan

a. Hambatan dalam Pemindahan Arsip

Berdasarkan hasil temuan yang dilakukan oleh peneliti ditemukan bahwa proses pemindahan arsip belum dilakukan penjadwalan pemindahan arsip secara berkala hanya dilakukan setahun sekali yakni pada akhir tahun pelajaran baru sehingga mengakibatkan terjadinya penumpukan arsip di lokasi kerja pencipta arsip tersebut dan penanganan terhadap pemindahan arsip dilakukan oleh petugas yang belum memahami mengenai pengelolaan arsip sehingga dalam proses pemindahan arsip masih belum maksimal.

\section{b. Hambatan dalam Penataan Arsip}

Lokasi ruang penyimpanan arsip yang tidak luas dan jumlah volume arsip yang semakin banyak serta minimnya peralatan dan perlengkapan arsip mengakibatkan adanya penumpukan arsip di lokasi tersebut sehingga penataan arsip masih belum optimal.

c. Hambatan dalam Penyimpanan Arsip

Kendala yang dihadapi oleh objek riset tersebut yakni minimnya sarana dan prasarana untuk penyimpanan arsip serta bertambahnya volume arsip mengakibatkan terjadinya penumpukan dan tidak tertatanya arsip di lokasi penyimpanan arsip dengan optimal sehingga terhambatnya proses penyimpanan arsip.

\section{d. Hambatan dalam peminjaman Arsip}

Wawancara yang dilakukan dengan bagian Tata Usaha SMK Diponegoro Karanganyar Kabupaten Pekalongan ditemukan kendala mengenai tidak tercatatnya arsip yang dipinjam sehingga petugas mengalami hambatan dalam penelusuran kembali terhadap arsip yang keluar atau yang dipinjam ke bagian lainnya sehingga akan mengakibatkan tidak ditemukan kembali arsip yang dipinjamkan atau terlambatnya pengembalian arsip ke bagian Tata Usaha SMK Diponegoro Karanganyar Kabupaten Pekalongan.

\section{e. Hambatan dalam Penemuan Kembali} Arsip

Volume arsip yang kian bertambah dan terbatasnya ruang penyimpanan arsip yang mengakibatkan adanya penumpukan arsip di tempat penyimpanan arsip serta pencatatan arsip yang dipinjam tidak maksimal dilakukan, melihat kondisi tersebut maka terhambatnya penemuan kembali arsip yang dibutuhkan atau membutuhkan waktu yang cukup lama untuk menemukkan arsip yang dicari.

\section{f. Hambatan dalam Pemeliharaan Arsip}

Kondisi fisik ruang penyimpanan yang terbatas dan banyaknya penumpukan arsip serta belum dibuatnya jadwal pemeliharaan arsip mengakibatkan adanya debu yang menempel di lemari arsip dan berkas serta suhu udara di ruang penyimpanan arsip panas dikarenakan tidak menggunakan AC mengakibatkan adanya kerusakan pada arsip tersebut.

\section{g. Hambatan dalam Pengamanan Arsip}

Kondisi udara didalam ruang penyimpanan arsip yang belum kondusif mengakibatkan banyaknya debu yang menempel di arsip dan suhu udara yang tidak sejuk dapat mengancam kondisi dari arsip tersebut. Disamping itu, arsip yang tercipta tidak langsung di alih media seperti dilakukan scan hal ini akan mempengaruhi keamanan dari arsip tersebut.

\section{h. Hambatan dalam Penyusutan Arsip}

Banyaknya arsip yang tercipta mengakibatkan adanya penumpukan dan SDM yang menangani arsip masih belum ada, mereka yang bertugas di bagian Tata Usaha mengalami hambatan dikala rutinitasnya di bagian Tata Usaha harus disisipkan kegiatan penyusutan arsip serta belum adanya jadwal retensi arsip oleh 
karena itu proses penyusutan arsip di SMK Diponegoro Karanganyar Kabupaten Pekalongan menjadi terhambat dan belum terlaksana dengan optimal.

3.3 Upaya Mengatasi Hambatan Dalam Pengelolaan Arsip Dinamis Inaktif Pada Bagian Tata Usaha Lembaga Pendidikan Sekolah Menengah Kejuruan

a. Upaya Mengatasi Hambatan dalam Pemindahan Arsip

Proses pemindahan arsip dari pencipta arsip ke lokasi penyimpanan arsip harus dibuat jadwal pemindahan arsip berdasarkan nilai guna dari arsip tersebut dan melakukan pengadaan sarana dan prasarana guna memaksimalkan proses penyimpan arsip sehingga terciptanya pengelolaan arsip yang baik.

b. Upaya Mengatasi Hambatan dalam Penataan Arsip

Untuk mengatasi volume arsip yang banyak maka harus dilakukan penambahan perlengkapan arsip seperti penambahan lemari arsip, box file, ordner, ring binder dan lain sebagainya. Disamping itu pula petugas yang mengelola arsip perlu melakukan langkah-langkah dalam penataan arsip dengan beberapa cara antara lain; sistem abjad, sistem nomor, sistem geografis, sistem subjek dan sistem kronologi hal tersebut bertujuan agar arsip yang disimpan tidak cepat rusak, tidak terjadi kehilangan barang, tersusun rapi sehingga mudah ditemukan apabila barang tersebut dicari, memudahkan dalam pengawasan dan analisa.

c. Upaya Mengatasi Hambatan dalam Penyimpanan Arsip

Disamping melakukan sistem penataan tersebut proses penyimpanan arsip dapat dilakukan dengan membuat indeks, memberikan kode pada arsip, melakukan penyortiran arsip berdasarkan kelompok atau klasifikasi sebelum dilakukan penyimpanan dan penyimpanan arsip yang ditempatkan pada lemari khusus arsip dan diberikan label.

\section{d. Upaya Mengatasi Hambatan dalam Peminjaman Arsip}

Agar tidak terjadi kehilangan arsip dikarenakan peminjaman arsip maka dapat dilakukan pencatatan atau pendataan arsip yang tersimpan di ruang arsip dengan menggunakan buku peminjaman dan kartu kendali hal tersebut agar ada nya pengawasan terhadap arsip yang keluar atau dipinjam sehingga terhindar dari kehilangan arsip tersebut.

Disamping itu perlu diberlakukannya aturan dalam peminjaman arsip, adapun yang harus diatur antara lain; siapa yang berwenang memberikan izin peminjaman, siapa yang diperbolehkan meminjam arsip, penetapan jangka waktu peminjaman arsip, tata cara peminjaman arsip dan dicatat pada lembar peminjaman arsip.

e. Upaya Mengatasi Hambatan dalam Penemuan Kembali Arsip

Agar memudahkan penemuan kembali arsip maka dilakukan penataan arsip yang baik dan melakukan penyortiran arsip yang dilakukan secara rutin supaya terhindar dari penumpukan arsip baik di tempat pencipta arsip maupun di tempat penyimpanan arsip.

\section{f. Upaya Mengatasi Hambatan dalam Pemeliharaan Arsip}

Arsip yang disimpan dalam keadaan baik atau siap pakai maka petugas yang menangani pengelolaan arsip perlu melakukan kegiatan pemeliharaan secara rutin atau berkala sesuai dengan jadwal rutin pemeliharaan dan melakukan pengadaan sarana dan prasarana seperti tersedianya kamper (kapur barus) guna mencegah hama, melakukan pembersihan debu, tersedianya alat pemadam kebakaran, pembuatan dan pemberlakuan SOP (Standard Operating Procedure), dan terjaganya suhu udara di ruang arsip.

\section{g. Upaya Mengatasi Hambatan dalam Pengamanan Arsip}

Dengan melakukan penjadwalan rutin untuk pemeliharaan arsip secara tidak langsung dapat menyelamatkan arsip yang disimpan. Disamping itu pula, melakukan alih media atau digitalisasi terhadap arsip yang tercipta seperti melakukan scan untuk arsip yang telah diciptakan dan melakukan penyimpanan arsip yang telah dialih media ke dalam program kearsipan yang dibuat. Jika belum membuat program kearsipan bisa dilakukan penyimpanan melalui email khusus atau google drive. Hal ini dilakukan guna meminimalisir kehilangan arsip. 


\section{h. Upaya Mengatasi Hambatan dalam Penyusutan Arsip}

Dikarenakan arsip memiliki nilai guna yang berbeda-beda maka tidak semua arsip harus dilakukan penyimpanan secara terus menerus melainkan ada sebagian arsip yang perlu dipindahkan bahkan dimusnahkan. Agar tidak terjadi penumpukan arsip maka dilakukan penyortiran arsip berdasarkan nilai guna arsip dan membuat jadwal retensi arsip serta melakukan pengadaan SDM yang khusus menangani arsip. Adapun kegiatan penyusutan arsip dapat dilakukan dengan cara; pemindahan arsip inaktif dari unit pengolah ke unit kearsipan, pemusnahan arsip sesuai dengan ketentuan yang berlaku dan menyerahkan arsip statis kepada Arsip Nasional RI.

\section{Kesimpulan}

Riset ini dapat disimpulkan bahwa pengelolaan arsip dinamis inaktif pada bagian Tata Usaha di SMK Diponegoro Karanganyar Kabupaten Pekalongan yakni bahwa proses pemindahan arsip yang ada disana belum maksimal dilakukan secara tersistem dan masih bersifat manual terbukti adanya program atau sistem kearsipan yang mendukung pengelolaan arsip dinamis inaktif di sekolah tersebut, adanya penumpukan arsip di ruang kerja sehingga membutuhkan waktu proses penataan arsip dan penemuan arsip kembali dikarenakan terbatasnya ruang penyimpanan arsip dan peralatan arsip, pemeliharaan arsip dilakukan dengan waktu yang masih tidak tentu karena belum ada jadwal rutin, belum adanya buku catatan peminjaman arsip, pengamanan arsip menjadi tanggung jawab setiap pegawai, dan Penyusutan arsip belum dilakukan secara sistematis serta minimnya pengetahuan SDM terkait tentang pengelolaan arsip.

Keterbatasan dalam riset ini adalah adanya keterbatasan informasi yang disampaikan oleh informan mengenai pengelolaan arsip dinamis inaktif karena pengelolaan arsip dinamis inaktif masih bersifat sederhana dan belum adanya sistem pengelolaan arsip dinamis inaktif berbasis digitalisasi. Belum maksimalnya penerapan prosedur mengenai pengelolaan arsip.

Saran untuk riset selanjutnya yakni penerapan sistem pengelolaan arsip dinamis inaktif berbasis digitalisasi guna meningkatkan efektivitas kerja dan penemuan arsip kembali serta pengamanan arsip di SMK Diponegoro Karanganyar Kabupaten Pekalongan.

\section{Referensi}

Ali Muhidin, S. (2019). Teori dan Praktek Sistem Kearsipan (1st ed.). CV Pustaka Setia.

Damalita, S. (2009). Pentingnya Manajemen Arsip di Lingkungan Perguruan Tinggi. Jurnal Ekonomi, Manajemen, Dan Bisnis (EMAS), 3(1), 1-10. http://library.um.ac.id/images/stories/arsiparis_u $\mathrm{m}$ /pentingnya manajemen arsip di lingkungan perguruan tinggi - susiasih d.pdf

Fathurrahman, M. (2018). Pentingnya Arsip Sebagai Sumber Informasi. JIPI (Jurnal Ilmu Perpustakaan Dan Informasi), 3(2), 215-225. https://core.ac.uk/download/pdf/266976326.pdf

Gavinov, I. T. (2016). Manajemen Perkantoran (1st ed.). Parama Publishing.

Jumiyati, E. (2009). Pengelolaan Arsip di Pusat Teknologi Bahan Bakar Nuklir. PIN Pengelolaan Instalasi Nuklir, 2(3), 55-62. http://jurnal.batan.go.id/index.php/pin/article/vie w/2530

Kuswantoro, A. (2015). Model Elektronok Arsip (E Arsip) Pembelajaran Berbasis Virtual dan Microsoft Access pada SMK Program Keahlian Administrasi Perkantoran. EFISIENSI - KAJIAN ILMU ADMINISTRASI, 3(2 Agustus 2015). https://doi.org/10.21831/efisiensi.v13i2.11679

Maryati. (2008). Manajemen Perkantoran Efektif. Unit Penerbit Dan Percetakan Sekolah Tinggi Ilmu Manajemen $Y K P N$.

Mulyapradana, A., \& Zulaekho, S. (2018). Implementasi Sistem Penyusutan Arsip Inaktif Di Unit Tata Usaha. Widya Cipta.

Mulyono, S., Partono, P., \& Kuswantoro, A. (2011). Manajemen Kearsipan (1st ed.). Unnes Press.

Ramanda, S. R., \& Indrahti, S. (2015). Analisis Pengelolaan Arsip Inaktif Terhadap Temu Kembali Arsip Di Pusat Arsip (Record Center) Politeknik Negeri Semarang. Jurnal Ilmu Perpustakaan, 4(3), 211-220. https://ejournal3.undip.ac.id/index.php/jip/article/ view/9741

Sanora, N. A. (2016). Pengelolaan Arsip Pada Bagian Tata Usaha Biro Umum Kantor Gubernur Provinsi Kalimantan Timur. EJournal Administrasi Negara, 4(2), 4042-4056. https://ejournal.ap.fisip-unmul.ac.id/site/wpcontent/uploads/2016/06/Jurnal (06-16-16-04-4838).pdf

Sedarmayanti. (2017). Manajemen Perkantoran Modern (R. M. Maju (ed.); 1st ed.). Penerbit CV. Mandar Maju.

Undang-Undang No. 43 Tahun 2009 Tentang Kearsipan

Veraniasyah, R. D. P., \& Erlangga Andi, S. (2019). 
Prosedur Pengelolaan Arsip Untuk Keamanan Dokumen Di Rsia Puri Bunda Malang. Jurnal Administrasi Dan Bisnis, 13(1), 65-74. http://jadbis.polinema.ac.id/index.php/adbis/artic le/view/66

Wirawanty, F. (2014). Tata Kelola Penyimpanan Arsip Dalam Upaya Meningkatkan Efisiensi Penemuan Kembali Arsip di Kantor Perpustakaan Umum dan Arsip Kabupaten Pamekasan. Jurnal Pendidikan Administrasi Perkantoran, 2(2), 1-16. https://jurnalmahasiswa.unesa.ac.id/index. php/jpap/article/view/9333/9248

Yatimah, D. (2020). Kesekretariatan Modern \& Administrasi Perkantoran. CV Pustaka Setia. 